\title{
One-Step Preparation of Potassium Acyltrifluoroborates
}

\section{Key words}

arenes

boron

lithiation

SYNFACThen

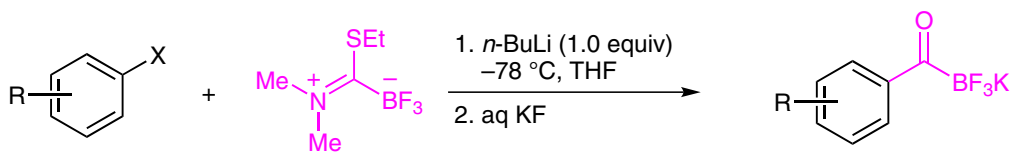

$\mathrm{R}=\mathrm{F}, \mathrm{Br}, \mathrm{OMe}, \mathrm{CN}, \mathrm{NO}_{2}, \mathrm{CO}_{2} \mathrm{Et}$, and various heterocycles

$\mathrm{X}=\mathrm{Br}, \mathrm{I}$

Selected examples:<smiles>CCOC(=O)c1cccc(C(=O)Br)c1</smiles>

$79 \%$ yield<smiles>O=C(Br)c1cccc(Cl)n1</smiles>

$81 \%$ yield<smiles>O=C(Br)c1ccc(Br)cc1</smiles>

$71 \%$ yield<smiles>CC(C)C(=O)c1ccc(Br)nc1</smiles>

$95 \%$ yield<smiles>O=C(Br)c1cc(C(F)(F)F)cc(C(F)(F)F)c1</smiles>

$89 \%$ yield<smiles>O=C(Br)c1cnc2ccccc2c1</smiles>

$77 \%$ yield<smiles>N#Cc1ccc(C(=O)Br)cc1</smiles>

$86 \%$ yield

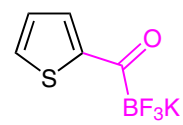

$89 \%$ yield
Significance: The authors report a novel reagent for the synthesis of potassium acyltrifluoroborates (KATs). These reagents are stable, soluble zwitterions prepared by S-alkylation of a thioformamide trifluoroboronate. Starting from aryl- and heteroaryl halides, the described protocol considerably expands the synthetic scope of acyl boron compounds.
Comment: Several new classes of boronates, including thioformamide, formamide, and imidate derivatives, were introduced in this work. The protocol is suitable for the preparation of KATs containing pyridines, esters, nitro groups, and halides. 